\title{
Differential modulation of inflammatory markers in plasma and skin after single exposures to UVA or UVB radiation in vivo
}

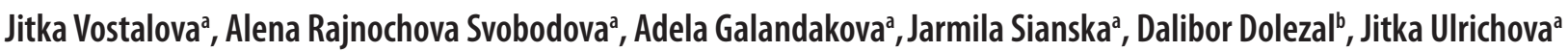

Background. Solar light generates inflammatory responses in exposed skin. These effects are generally attributed to UVB light. However, skin is exposed to a huge quantum of UVA photons as UVA is a predominant part of sunlight and the radiation used in tanning beds. We examined the effects of a single exposure to UVA and UVB wavebands on cytokine levels in skin and plasma, myeloperoxidase (MPO) activity, expression of inducible nitric oxide synthase (iNOS) and cyclooxygenase 2 (COX-2) in skin.

Methods. Hairless mice were irradiated with either UVA (10 or $\left.20 \mathrm{~J} / \mathrm{cm}^{2}\right)$ or UVB $\left(200\right.$ or $\left.800 \mathrm{~mJ} / \mathrm{cm}^{2}\right)$. The effects were assessed after $4 / 24 \mathrm{~h}$. Plasma cytokine levels were evaluated using a Bio-Plex cytokine assay. Cytokine, iNOS and COX-2 levels in skin were determined by Western blot. Skin MPO activity was monitored spectrophotometrically.

Results. UVB induced up-regulation of interleukin-1 $\beta$ (IL-1 $\beta$ ) and interleukin-6 (IL-6) and decrease in interleukin-10 (IL-10) mainly after $4 \mathrm{~h}$. In contrast, UVA caused increase in levels of tumor necrosis factor-alpha (TNF- $a$ ) and IL-6 after $4 \mathrm{~h}$ and up-regulated IL-10 and interleukin-12 (IL-12) after $24 \mathrm{~h}$. The increase in MPO activity from infiltrated leucocytes was observed only in UVB irradiated animals. iNOS was up-regulated $4 \mathrm{~h}$ after UVA and UVB treatment. No significant effect on COX-2 expression was detected.

Conclusions. UVA and UVB light affected several inflammatory markers. For individual waveband, changes in plasma parameters did not correlate with those in skin. Thus evaluation of plasma samples cannot simply be replaced by determination in skin specimens and vice versa.

Key words: solar radiation, hairless mice, cytokine, myeloperoxidase, nitric oxide synthase, cyclooxygenase-2

Received: November 20, 2012; Accepted with revision: April 30, 2013; Available online: June 3, 2013 http://dx.doi.org/10.5507/bp.2013.036

${ }^{a}$ Department of Medical Chemistry and Biochemistry, Faculty of Medicine and Dentistry, Palacky University Olomouc, Czech Republic ${ }^{b}$ Center for Laboratory Animals, Faculty of Medicine and Dentistry, Palacky University Olomouc Corresponding author: Alena Rajnochova Svobodova, e-mail:alf.svoboda@seznam.cz

\section{INTRODUCTION}

Human skin is normally exposed exclusively to wavelengths $>294 \mathrm{~nm}$, as ozone in the stratosphere completely absorbs shorter wavelengths ${ }^{1}$. UVB wavelengths (295-315 nm) represent a minor (5-10\%) but biologically very active part of incoming UV light. UVB is predominantly absorbed within epidermal layers and only a small fraction $(\sim 10 \%)$ reaches the dermis. In contrast, UVA (315-400 nm) is very abundant in incoming UV radiation (90-95\%). It penetrates deep into the dermis $(\sim 50-70 \%)$ and even hypodermis $(\sim 10 \%)\left(\right.$ ref. $\left.^{2}\right)$.

Biological effects of UV radiation on skin include the inflammatory response. Characteristic findings after overexposure to sunlight are erythema, swelling and pain. Histopathologic changes include keratinocyte damage, Langerhans' cell depletion, dermal edema, mast cell degranulation, inflammatory cell infiltration and alteration to vascular functions ${ }^{3}$. Biochemical changes include increase in myeloperoxidase (MPO) activity and cyclooxygenase-2 (COX-2) expression, generation of arachidonic acid products and cytokines ${ }^{4,5}$. All these substances very likely assist in mediating the inflammatory reaction. Cytokines affect other outlying cells, mediating cellular growth and differentiation as well as inflammatory and immune reactions. Thus, cytokines contribute to maintaining/disruption of cellular and intercellular homeostasis according to the actual concentration ${ }^{6}$.

Over decades, investigation has focused on specific and non-specific immune responses to UVB light, although sunlight as well as tanning lamps used in tanning beds are primarily UVA sources ${ }^{3}$. UVB exposure has been shown to augment production of various cytokines including tumor necrosis factor-alpha (TNF- $\alpha$ ), IL- $1 \alpha$, IL- $1 \beta$, IL-6, IL-8, IL-10 in human and/or mice skin ${ }^{7}$. Recent studies have provided evidence that UVA light can also affect the immune system. Similar cytokines have been identified as secreted on UVA exposure in keratinocytes in vitro ${ }^{1,8}$. Studies further suggest that UVA influences the immune system probably in a different way than UVB and that the consequences of UVA and UVB may interact with each other'. Apropos UVA and UVB penetration of the skin, UVB probably has more effect on the epidermis and UVA on the dermis. However, immunoregulatory effects of UVA have not been fully investigated and explained. The aim of this study was to examine and compare shorttime ( 4 and $24 \mathrm{~h}$ ) effects of single UVA or UVB exposure on selected inflammatory markers in hairless mice. 


\section{MATERIALS AND METHODS}

Material. Bio-Plex Pro $^{\mathrm{TM}}$ Mouse Cytokines Group I kit was purchased from BioRad (USA). Rabbit polyclonal primary antibody anti-TNF- $\alpha,-$ IL- $1 \alpha,-$ IL-1 $\beta$, -IL-6, -IL-10(p40), -IL-12, -COX-2, -iNOS, goat polyclonal primary antibody anti-actin and goat anti-rabbit and rabbit anti-goat horseradish peroxidase (HRP) conjugated secondary antibodies were purchased from Santa Cruz Biotechnology (USA). All other chemicals were purchased from Sigma-Aldrich (USA).

Animals. Female SKH-1 hairless mice were from a breeding facility Charles River Deutschland (supply equipment: AnLab s.r.o, Praha). Mice were housed in the animal facility and were maintained throughout under standard conditions: $22 \pm 2{ }^{\circ} \mathrm{C}, 50 \pm 10 \%$ relative humidity and $12 \mathrm{~h} \mathrm{light} / 12 \mathrm{~h}$ dark cycle. They were fed a standard diet (St-1 - complete mixture for rats and mice in the SPF breeding; supply equipment: VELAZ, s.r.o. Únětice) and water ad libitum. The animal protocol for the study was approved by the Institutional Animal Care and Use Committee of the Faculty of Medicine and Dentistry of Palacký University and Ethics Committee of Ministry of Education, Czech Republic and conducted in accordance with the Act No. 167/1993 on the protection of animals against cruelty.

UV irradiation. To approach the experimental conditions as close to natural conditions as possible, a solar simulator SOL-500 (Dr. Hönle UV Technology), with a spectral range (295-3000 nm) corresponding to natural sunlight, and environmentally relevant UVA (10 or $\left.20 \mathrm{~J} / \mathrm{cm}^{2}\right)$ and UVB $\left(200\right.$ or $\left.800 \mathrm{~mJ} / \mathrm{cm}^{2}\right)$ doses were employed. The simulator was equipped with a $\mathrm{Hl}$ or $\mathrm{H} 2$ filter transmitting wavelengths of $315-380 \mathrm{~nm}$ or $295-315 \mathrm{~nm}$, respectively. The mice were randomly divided into 6 groups of 8 animals and dorsal skin was exposed to a single dose of UVB or UVA.

Sample collection. Blood samples were collected into $\mathrm{Na}_{2}$ EDTA under ether anaesthesia at 4 or $24 \mathrm{~h}$ after exposure. The blood was centrifuged $(2500 \mathrm{rpm}, 10 \mathrm{~min}$, $4{ }^{\circ} \mathrm{C}$ ) to obtain the plasma, which was stored at $-80{ }^{\circ} \mathrm{C}$. The mice were then killed by cervical dislocation. The dorsal skin was removed, washed in cold phosphate buffered saline, the subcutis was discarded and the skin was stored at $-80^{\circ} \mathrm{C}$.

Plasma cytokine determination. Levels of IL- $1 \alpha$, IL- $1 \beta$, IL-6, IL-10, IL-12 (p40), IL-12 (p70), IFN- $\gamma$, TNF- $\alpha$ in plasma were determined using Bio-Plex Mouse Cytokines Group I ELISA kit and Bio-Plex 200 System (BioRad, USA) according to the manufacturer's manual at the Laboratory of Diagnostics of Autoimmune Diseases, Academy of Sciences (Prague, Czech Republic).

Skin cytokines determination. Skin samples were homogenized in ice-cold cell lysis buffer $(50 \mathrm{mM}$ Tris$\mathrm{HCl}, \mathrm{pH}$ 7.4; $150 \mathrm{mM} \mathrm{NaCl} ; 1 \mathrm{mM}$ EDTA; $1 \mathrm{mM}$ EGTA; $20 \mathrm{mM} \mathrm{NaF} ; 100 \mathrm{mM}$ sodium orthovanadate; $0.5 \%$ NP-40; $1 \%$ Triton X-100; $1 \mathrm{mM}$ phenylmethanesulfonylfluoride; and protease inhibitor cocktail tablet). The homogenate was incubated $30 \mathrm{~min}$ on ice and centrifuged $\left(14000 \mathrm{rpm}, 20 \mathrm{~min}, 4^{\circ} \mathrm{C}\right)$. The supernatants were collected for western blot analysis and stored at $-80{ }^{\circ} \mathrm{C}$. Samples were pooled and the protein content was determined by Bradford assay. Proteins were separated by $8 \%$ or $12.5 \%$ SDS-polyacrylamide gel electrophoresis, and blotted onto polyvinylidene difluoride membrane. Residual binding sites on the membrane were blocked using blocking buffer $(100 \mathrm{mM}$ Tris buffered saline (pH 7.5); Tween 20 (0.05\%; v/v); non-fat dry milk (5\%; $\mathrm{w} / \mathrm{v})$ ) for $1 \mathrm{~h}$ at room temperature. The membrane was then incubated with a primary antibody (rabbit antiTNF- $\alpha$, -IL-1 $\alpha$, -IL-1 $\beta$, -IL-6, -IL-10(p40), -IL-12, -iNOS, -COX-2 or goat anti-actin; in blocking buffer) overnight at $4{ }^{\circ} \mathrm{C}$ and then with a secondary HRP conjugated antibody (goat anti-rabbit antibody/rabbit anti-goat antibody; in blocking buffer) for $2 \mathrm{~h}$ at room temperature. The immunocomplex of individual proteins was detected by chemiluminiscence using Western Blotting Luminol Reagent and autoradiography with XAR-5 film. The quantification of protein was performed by dosimetric analysis using ElfoMan 2.6 software.

MPO activity determination. The UV-induced leukocyte migration to the skin of hairless mice was evaluated using the MPO kinetic-colorimetric assay as previously described $^{10}$. Samples of the total skin of hairless mice (1:20 dilution) were homogenized in $50 \mathrm{mM}$ phosphate buffer (pH 6.0) and centrifuged (14 $000 \mathrm{rpm}, 10 \mathrm{~min}, 4^{\circ} \mathrm{C}$ ). The supernatant was discarded and the proteinaceous pellet was solubilised in $0.5 \mathrm{~mL}$ of ice-cold in $50 \mathrm{mM}$ phosphate buffer ( $\mathrm{pH} 6.0$ ) with $0.5 \%$ hexadecyltrimethylammonium bromide (HTAB). Solubilisation was accomplished using a probe-type sonicator ( 10 bursts at an instrument power setting of $50 \%$ ) followed by freeze-thaw ( 3 cycles). Then homogenates were centrifuged $\left(14000 \mathrm{rpm}, 10 \mathrm{~min}, 4^{\circ} \mathrm{C}\right)$ and the supernatants were collected. The MPO activity of the skin tissue extracts was determined spectrophotometrically by continually monitoring the change in absorbance at $460 \mathrm{~nm}$ for a period of $3 \mathrm{~min}$. Briefly, $1.76 \mathrm{~mL}$ of reaction mixture $(50 \mathrm{mM}$ phosphate buffer $(\mathrm{pH} 6.0)$ containing $0.5 \mathrm{mM}$ o-dianisidine dihydrochloride and $0.25 \mathrm{mM}$ HTAB) was mixed with $40 \mu \mathrm{L}$ of sample. The reaction was initiated by addition of the substrate, hydrogen peroxide $(3 \mathrm{mM} ; 200 \mu \mathrm{L})$. The results are presented as units/g protein.

Statistical analysis. The data were expressed as mean $\pm \mathrm{SD}$ and a $t$-test was used for testing the significance of differences.

\section{RESULTS}

Effects on plasma cytokine levels. Four hours after exposure, the lower UVB dose significantly decreased IL-10 levels only $(P<0.001)$. The higher UVB dose reduced secretion of IL-10 and markedly increased levels of IL-1 $\beta$ and IL-6 to 1.25 -fold and 24.7-fold, respectively (Table 1). At $24 \mathrm{~h}$ following UVB treatment, the IL-6 level was significantly enhanced in both irradiated groups. TNF- $\alpha$ concentration remained elevated in the group exposed to $200 \mathrm{~mJ} / \mathrm{cm}^{2}$ compared to controls (Table 1).

An increase in IL- 6 and TNF- $\alpha$ secretion was detect- 
Table 1. The plasma cytokine concentrations after UVB exposure.

Data represent results from 4 mice per group. Values are given in mean \pm SD. The statistical significance of difference between control and UVB treated group was determined by Student $t$-test; $\left(^{*}\right) P<0.001$ and (\#) $P<0.05$.

\begin{tabular}{|c|c|c|c|c|}
\hline \multirow{2}{*}{ Hours } & \multirow{2}{*}{$\begin{array}{l}\text { Parameter } \\
(\mathrm{pg} / \mathrm{mL})\end{array}$} & \multicolumn{3}{|c|}{ Group of animals } \\
\hline & & Unirradiated & $200 \mathrm{~mJ} / \mathrm{cm}^{2} \mathrm{UVB}$ & $800 \mathrm{~mJ} / \mathrm{cm}^{2} \mathrm{UVB}$ \\
\hline \multirow{6}{*}{$4 \mathrm{~h}$} & IL-1 $\alpha$ & $8.1 \pm 2.4$ & $14.2 \pm 5.9$ & $7.7 \pm 1.2$ \\
\hline & IL-1 $\beta$ & $55.4 \pm 7.4$ & $53.4 \pm 6.4$ & $69.2 \pm 6.0^{\#}$ \\
\hline & IL-6 & $2.4 \pm 1.9$ & $5.0 \pm 2.8$ & $59.3 \pm 28.9^{\#}$ \\
\hline & TNF- $\alpha$ & $13.0 \pm 6.4$ & $13.6 \pm 3.7$ & $22.1 \pm 7.8$ \\
\hline & IL-10 & $21.6 \pm 4.6$ & $5.0 \pm 1.2^{*}$ & $6.7 \pm 4.2^{\#}$ \\
\hline & IL-12(p40) & $279.3 \pm 58.6$ & $277.1 \pm 8.5$ & $352.8 \pm 38.2$ \\
\hline \multirow{6}{*}{$24 \mathrm{~h}$} & IL-1 $\alpha$ & $10.7 \pm 5.6$ & $9.4 \pm 3.7$ & $9.9 \pm 3.6$ \\
\hline & IL-1 $\beta$ & $55.2 \pm 6.6$ & $61.4 \pm 18.4$ & $47.4 \pm 13.9$ \\
\hline & IL-6 & $1.9 \pm 0.4$ & $10.3 \pm 6.2^{\#}$ & $47.5 \pm 23.3^{\#}$ \\
\hline & TNF- $\alpha$ & $14.1 \pm 1.5$ & $23.3 \pm 3.8^{\#}$ & $17.5 \pm 14.5$ \\
\hline & IL-10 & $15.1 \pm 9.2$ & $22.8 \pm 7.8$ & $12.8 \pm 6.5$ \\
\hline & IL-12(p40) & $258.7 \pm 6.4$ & $250.5 \pm 26.8$ & $205.2 \pm 57.2$ \\
\hline
\end{tabular}

Table 2. The plasma cytokine concentrations after UVA exposure.

Data represent results from 4 mice per group. Values are given in mean $\pm \mathrm{SD}$. The statistical significance of difference between control and UVA treated group was determined by Student $t$-test; (*) $P<0.005$ and (\#) $P<0.05$.

\begin{tabular}{|c|c|c|c|c|}
\hline \multirow{2}{*}{ Hours } & \multirow{2}{*}{$\begin{array}{c}\text { Parameter } \\
(\mathrm{pg} / \mathrm{mL})\end{array}$} & \multicolumn{3}{|c|}{ Group of animals } \\
\hline & & Unirradiated & $10 \mathrm{~J} / \mathrm{cm}^{2} \mathrm{UVA}$ & $20 \mathrm{~J} / \mathrm{cm}^{2} \mathrm{UVA}$ \\
\hline \multirow{6}{*}{$4 \mathrm{~h}$} & IL-1 $\alpha$ & $6.9 \pm 2.7$ & $5.9 \pm 1.1$ & $4.0 \pm 2.2$ \\
\hline & IL-1 $\beta$ & $51.8 \pm 6.3$ & $62.7 \pm 12.6$ & $60.2 \pm 15.4$ \\
\hline & IL-6 & $2.9 \pm 1.4$ & $46.2 \pm 15.6^{*}$ & $198.5 \pm 36.4^{*}$ \\
\hline & TNF- $\alpha$ & $8.0 \pm 1.5$ & $23.5 \pm 2.1^{*}$ & $28.1 \pm 6.6^{*}$ \\
\hline & IL-10 & $26.0 \pm 6.5$ & $25.0 \pm 4.6$ & $26.5 \pm 15.4$ \\
\hline & IL-12(p40) & $266.7 \pm 71.2$ & $285.7 \pm 96.4$ & $361.4 \pm 88.4$ \\
\hline \multirow{6}{*}{$24 \mathrm{~h}$} & IL-1 $\alpha$ & $4.6 \pm 2.1$ & $4.5 \pm 2.1$ & $6.9 \pm 3.2$ \\
\hline & IL-1 $\beta$ & $55.5 \pm 8.4$ & $44.3 \pm 6.7$ & $65.4 \pm 6.5$ \\
\hline & IL-6 & $1.5 \pm 0.5$ & $5.4 \pm 1.8^{\#}$ & $11.5 \pm 6.7^{\#}$ \\
\hline & TNF- $\alpha$ & $8.8 \pm 0.1$ & $11.0 \pm 3.9$ & $8.9 \pm 3.2$ \\
\hline & IL-10 & $21.8 \pm 6.6$ & $42.0 \pm 4.8^{\#}$ & $42.2 \pm 7.4^{\#}$ \\
\hline & IL-12(p40) & $221.3 \pm 63.2$ & $214.1 \pm 45.8$ & $340.9 \pm 53.8^{\#}$ \\
\hline
\end{tabular}

ed $4 \mathrm{~h}$ after UVA treatment. The higher UVA dose also non-significantly enhanced the IL-12(p40) level at this time-point. At $24 \mathrm{~h}$ after irradiation, IL-6 concentration decreased compared to that at $4 \mathrm{~h}$ but the higher level persisted significant compared to control mice. The TNF- $\alpha$ concentration normalized in both irradiated groups. Significant increase in IL-10 level was found in both irradiated groups. The higher dose also induced a significant enhancement of IL-12(p40) level (Table 2).

Under our experimental conditions, the level of IL-12(p70) and INF- $\gamma$ in both UVA and UVB irradiated animals was under the declared assay quantification limit ( $1.53 \mathrm{pg} / \mathrm{mL}$ and $1.84 \mathrm{pg} / \mathrm{mL}$, respectively).
Effects on skin cytokine expression. Skin cytokine levels (Fig. 1, Table 3 and 4) detected by Western blot do not correlate highly with plasma levels analysed by the ELISA assay. The IL- $1 \alpha$ level was increased in the group treated with lower UVB dose after $4 \mathrm{~h}$ and decreased in both groups after $24 \mathrm{~h}$. IL- $1 \alpha$ expression was reduced in mice exposed to the lower UVA dose at both time points and to $20 \mathrm{~J} / \mathrm{cm}^{2}$ after $4 \mathrm{~h}$. We found an increased IL-1 $\beta$ level in the group exposed to $200 \mathrm{~mJ} / \mathrm{cm}^{2}$ of UVB after 4 and $24 \mathrm{~h}$. The effect of UVA radiation on IL-1 $\beta$ level contrasted after $4 \mathrm{~h}$. A dose of $10 \mathrm{~J} / \mathrm{cm}^{2}$ increased and the dose decreased levels. Normalization was found $24 \mathrm{~h}$ after UVA exposure. TNF- $\alpha$ level was nearly unaffected in skin irradiated with UVB waveband. In UVA exposed 
Table 3. The skin cytokine concentrations after UVB exposure. Data represent a quantification of Western blot analysis results obtained from pooled skin homogenates of 4 mice per group. The quantification of protein was performed by dosimetric analysis using ElfoMan 2.6 software.

\begin{tabular}{|c|c|c|c|c|}
\hline \multirow{2}{*}{\multicolumn{2}{|c|}{$\begin{array}{l}\text { Relative density } \\
\text { protein//actin }\end{array}$}} & \multicolumn{3}{|c|}{ UVB $\left(\mathrm{mJ} / \mathrm{cm}^{2}\right)$} \\
\hline & & $\mathbf{0}$ & 200 & 800 \\
\hline \multirow{6}{*}{$4 \mathrm{~h}$} & IL- $1 \alpha$ & 0.246 & 0.359 & 0.289 \\
\hline & IL-1 $\beta$ & 0.441 & 0.550 & 0.429 \\
\hline & IL-6 & 0.761 & 0.853 & 0.746 \\
\hline & TNF- $\alpha$ & 0.572 & 0.523 & 0.589 \\
\hline & IL-10 & 0.539 & 0.504 & 0.514 \\
\hline & IL-12(p40) & 0.169 & 0.281 & 0.247 \\
\hline \multirow{6}{*}{$24 \mathrm{~h}$} & IL- $1 \alpha$ & 0.353 & 0.234 & 0.224 \\
\hline & IL-1 $\beta$ & 0.576 & 0.650 & 0.521 \\
\hline & IL-6 & 0.676 & 0.603 & 0.387 \\
\hline & TNF- $\alpha$ & 0.565 & 0.609 & 0.549 \\
\hline & IL-10 & 0.383 & 0.469 & 0.497 \\
\hline & IL-12(p40) & 0.178 & 0.278 & 0.618 \\
\hline
\end{tabular}

Table 4. The skin cytokine concentrations after UVA exposure. Data represent a quantification of Western blot analysis results obtained from pooled skin homogenates of 4 mice per group. The quantification of protein was performed by dosimetric analysis using ElfoMan 2.6 software.

\begin{tabular}{llccc}
\hline \multicolumn{2}{c}{$\begin{array}{c}\text { Relative density } \\
\text { protein//actin }\end{array}$} & $\mathbf{0}$ & $\mathbf{1 0}$ & $\mathbf{2 0}$ \\
\hline \multirow{2}{*}{$4 \mathrm{UVA}\left(\mathbf{J} / \mathbf{c m}^{2}\right)$} \\
IL-1 $\alpha$ & 0.487 & 0.343 & 0.289 \\
IL-1 $\beta$ & 0.613 & 0.657 & 0.429 \\
& IL-6 & 0.996 & 0.863 & 0.746 \\
& TNF- $\alpha$ & 0.691 & 0.809 & 0.589 \\
& IL-10 & 0.566 & 0.582 & 0.514 \\
IL-12(p40) & 0.459 & 0.382 & 0.247 \\
\hline \multirow{4}{*}{$24 \mathrm{~h}$ IL-1 $\alpha$} & 0.507 & 0.302 & 0.224 \\
& IL-1 $\beta$ & 0.662 & 0.553 & 0.521 \\
IL-6 & 0.835 & 0.934 & 0.387 \\
TNF- $\alpha$ & 0.810 & 0.866 & 0.549 \\
IL-10 & 0.567 & 0.788 & 0.497 \\
IL-12(p40) & 0.377 & 0.586 & 0.618 \\
\hline
\end{tabular}

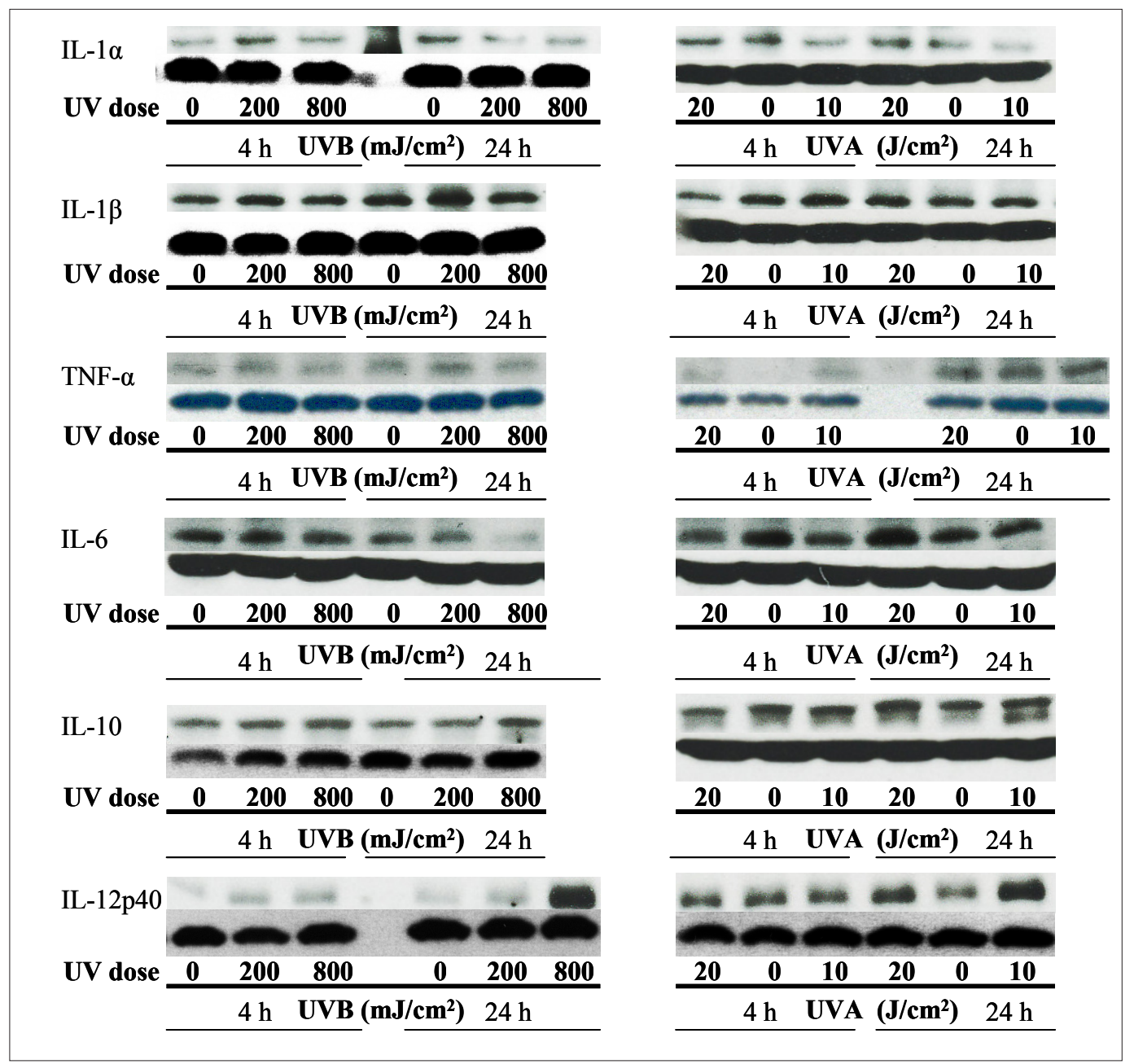

Fig. 1. Effects of UVA and UVB irradiation on cytokine expression in hairless mice skin. Immunoblot analysis of selected proteins in pooled skin homogenates of hairless mice exposed to a single dose of UVA and UVB sacrificed 4 and $24 \mathrm{~h}$ after irradiation was performed as described in Materials and Methods. The quantification of protein is shown in Table 3 (UVB) and 4 (UVA). 


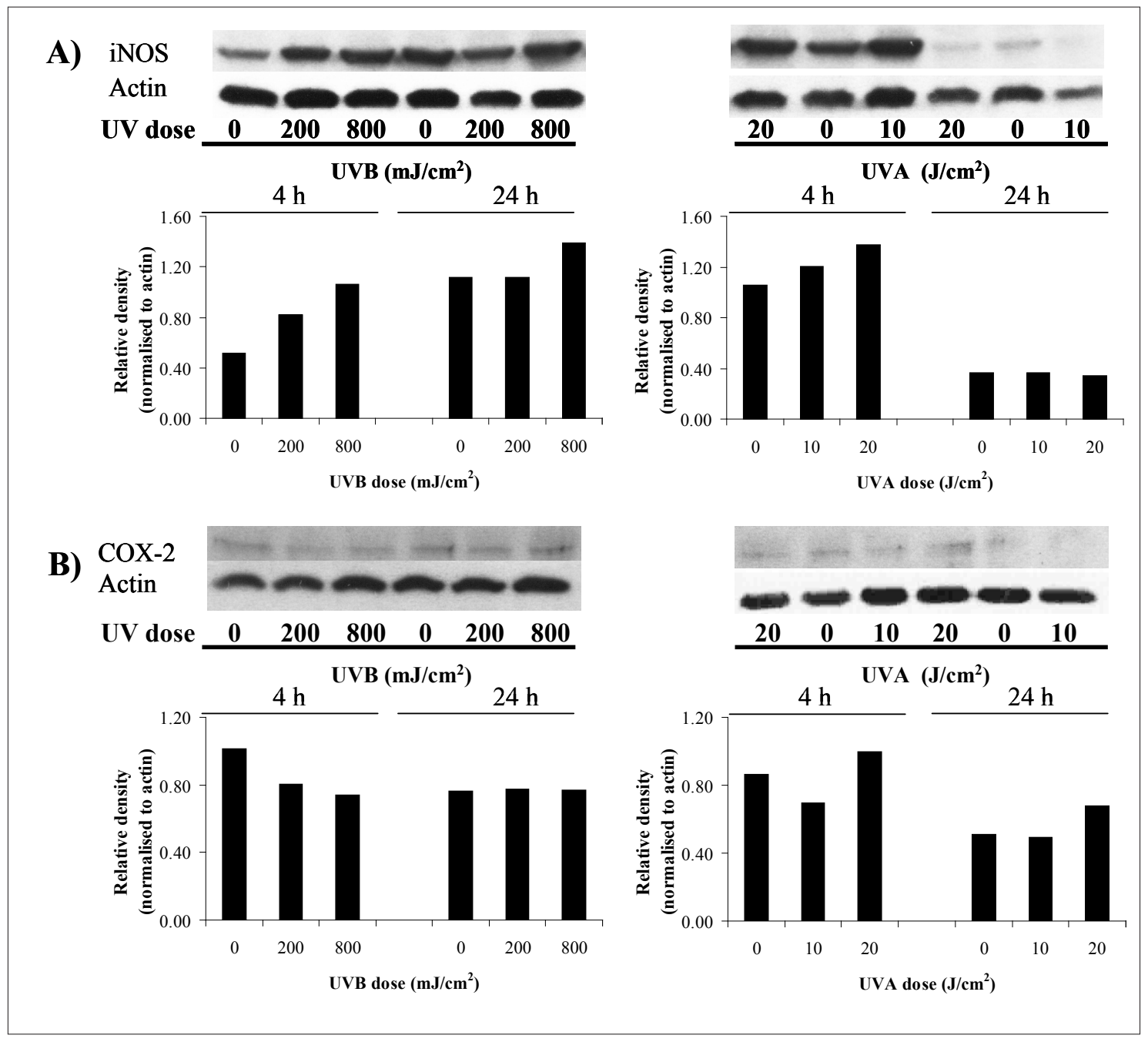

Fig. 2. Effects of UVA and UVB irradiation on iNOS and COX-2 expression in hairless mice skin. Immunoblot analysis of the proteins in pooled skin homogenates of hairless mice exposed to a single dose of UVA and UVB sacrificed 4 and $24 \mathrm{~h}$ after irradiation was performed as described in Materials and Methods. The quantification of protein was performed by dosimetric analysis using ElfoMan 2.6 software.

mice TNF- $\alpha$ was markedly elevated after $4 \mathrm{~h}$ in agreement with plasma results. $24 \mathrm{~h}$ following UVA irradiation the increase in TNF- $\alpha$ level was found only in the skin. IL-6 expression was not significantly affected following UVB irradiation except for a reduction caused by the higher dose after $24 \mathrm{~h}$. However these results do not correlate with plasma cytokine level that was significantly augmented. UVA treatment induced a dose-dependent decrease in IL-6 after $4 \mathrm{~h}$ that contrasts with plasma level. However, an obvious increase was found in animals exposed to UVA after 24 h. IL-10 expression in UVB treated mice was nearly unchanged after $4 \mathrm{~h}$ and increased $24 \mathrm{~h}$ after exposure. UVA caused up-regulation of IL-10 in both irradiated groups $24 \mathrm{~h}$ following irradiation that corresponded to plasma levels. IL-12(p40) was augmented in both UVB treated groups at both time-points, especially in mice exposed to the higher UVB dose after $24 \mathrm{~h}$. However, plasma IL-12(p40) level was moderately enhanced only in animals treated with the higher UVB dose $4 \mathrm{~h}$ after exposure. UVA waveband induced IL-12(p40) increase in both irradiated groups after $4 \mathrm{~h}$ that only partially correlates with plasma levels (Fig. 1, Table 3 and 4).

Effects on iNOS and COX-2 expression in skin. Expression of iNOS was significantly increased $4 \mathrm{~h}$ following UVB treatment. After $24 \mathrm{~h}$ the level was reduced in the group treated with the lower UVB dose. In UVA irradiated mice, iNOS was increased $4 \mathrm{~h}$ after exposure and normalized within $24 \mathrm{~h}$ (Fig. 2A). No significant effect of either UVA or UVB light was found on COX-2 expression (Fig. 2B).

Effects on skin MPO activity. In UVB exposed animals, no changes in skin MPO activity were observed after $4 \mathrm{~h}$, but a significant dose-dependent increase was found after $24 \mathrm{~h}$ (Fig. 3A). UVA caused no significant alteration to MPO activity in exposed mice (Fig. 3B). 


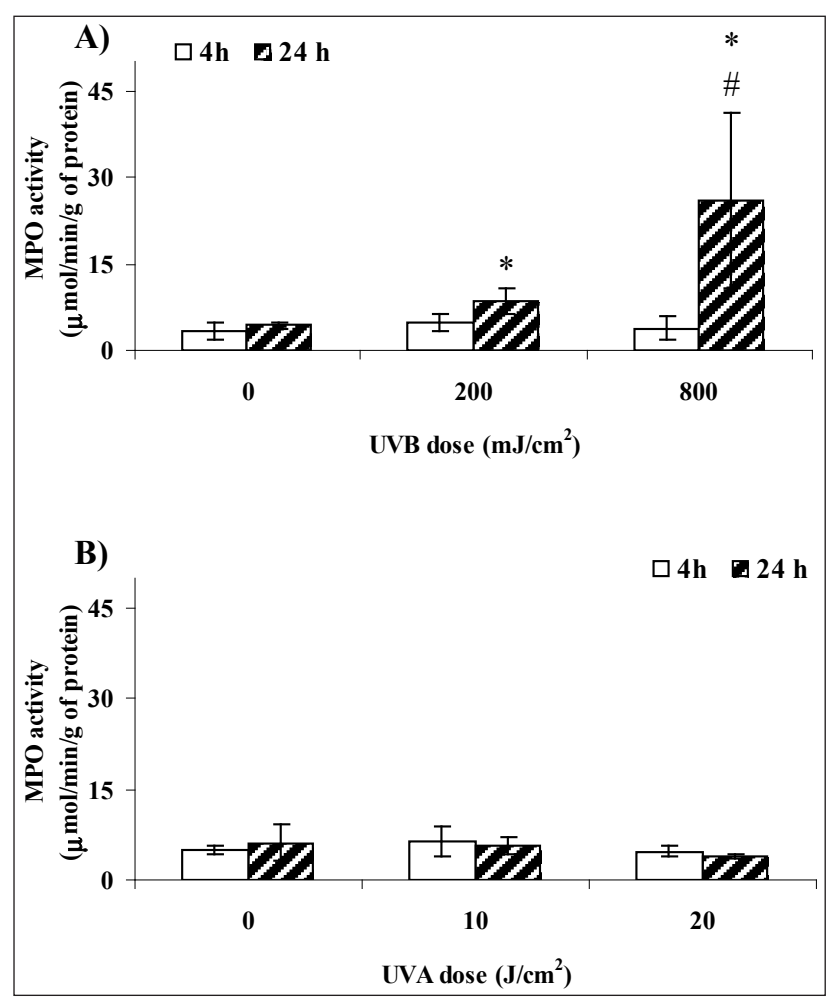

Fig. 3. Effects of UVA and UVB irradiation on MPO activity in hairless mice skin.

Female hairless mice were exposed to a single dose of UVB (200 and $\left.800 \mathrm{~mJ} / \mathrm{cm}^{2}\right)(\mathrm{A})$ and UVA $\left(10\right.$ and $\left.20 \mathrm{~J} / \mathrm{cm}^{2}\right)(\mathrm{B})$ and sacrificed 4 and $24 \mathrm{~h}$ after irradiation. Measurements were performed in skin as described in Materials and Methods. The values are expressed as mean \pm S.D. of 4 animals per group. The value $(*)$ and $(\#)$ is significantly different $(P<0.05)$ from that of non-irradiated group of animals and from that of the group irradiated with the UVB dose of $200 \mathrm{~mJ} / \mathrm{cm}^{2}$, respectively. Statistical significance was determined by t-test.

\section{DISCUSSION}

Altered dermal and epidermal cytokine profiles have been implicated in the pathophysiology of various skin disorders and the sunburn reaction ${ }^{11}$. IL- 1 and TNF- $\alpha$ have traditionally been understood to be the main inducer cytokines in the acute phase of inflammatory reaction ${ }^{12}$. In consensus we found increased plasma levels of TNF- $\alpha$ $4 \mathrm{~h}$ after UVA exposure while after $24 \mathrm{~h}$ the levels were normalized. Only the lower UVB dose showed increased TNF- $\alpha$ level after $24 \mathrm{~h}$. Similar changes in TNF- $\alpha$ level were found in UVB exposed skin. Levels of IL- $1 \alpha$ and IL-1 $\beta$ in plasma were unaffected following UVA and UVB treatment except for an increased IL-1 $\beta$ level in the group exposed to the higher UVB dose $4 \mathrm{~h}$ after irradiation (Table 1 and 2). On other hand, in skin we found UVA- and UVB-caused modulation of IL- 1 and IL- $1 \beta$ but it was not dose- either time-dependent. The lower UVA and UVB dose was more effective and induced increase/ decrease in those cytokines. The changes found in skin did not correlate with those in plasma. Comparing our results to published ones, Brink et al. demonstrated that sectional exposure of human volunteers to 1 and
3 MED $\left(1.8-3.6 \mathrm{~J} / \mathrm{cm}^{2}\right)$ of solar simulated light (SSL, $290-400 \mathrm{~nm}$ ) strongly elevated IL-1 $\beta$ and TNF- $\alpha$ mRNA levels in the skin $6 \mathrm{~h}$ after irradiation and then the levels decreased at $24 \mathrm{~h}$ ( ref. $^{13}$ ). A single exposure of human subjects to $3 \mathrm{MED}$ of SSL (290-400 nm; 1.4-5.6 J/m²) also caused a rapid increase in TNF- $\alpha$ level in blister fluid that started at $4 \mathrm{~h}$, peaked at $15 \mathrm{~h}$ and was normalized 48 $\mathrm{h}$ after exposure. On the other hand, IL- $1 \alpha$ and IL- $1 \beta$ level in blister fluid was significantly increased only at $15 \mathrm{~h}$ and remained elevated to $72 \mathrm{~h}$ after SSL exposure ${ }^{14}$. Similarly Hiromi et al. showed a rapid up-regulation of IL- $1 \alpha$ expression induced by UVB $\left(275-305 \mathrm{~nm} ; 200 \mathrm{~mJ} / \mathrm{cm}^{2}\right)$ in the skin of the Hirosaki hairless rats. IL- $1 \alpha$ protein increased after $3 \mathrm{~h}$, peaked at $6 \mathrm{~h}$ and gradually decreased during 12-24 $\mathrm{h}$ after exposure ${ }^{15}$. In another trial, nonsignificant changes, decrease in TNF- $\alpha$ and increase in IL-1 $\beta$, were found in blister fluid after sectional exposure of skin to SSL ( 1 and 2 MED) after $24 \mathrm{~h}$ (ref. ${ }^{16}$ ). Narbutt et al. found increased mRNA levels of IL-1 $\beta$ and TNF- $\alpha$ in human skin $24 \mathrm{~h}$ after a single local UVB $(280-315 \mathrm{~nm})$ exposure of $3 \mathrm{MED}$ ( ref. $^{17}$ ). In contrast, no significant changes in TNF- $\alpha$ and IL- $1 \beta$ level were found in plasma of human subjects at $24 \mathrm{~h}$ following a single exposure to 3 MED of UVB (280-315 nm). Repeated UVB irradiation ( 10 x $0.7 \mathrm{MED}$ ) induced a statistically significant increase only in plasma TNF- $\alpha$ level; no effect was found on IL-1 $\beta$ levels ${ }^{18}$. Repeated SSL (280-400 nm; $96 \%$ UVA) exposures $\left(10 \times 120 \mathrm{~J} / \mathrm{m}^{2}\right)$ caused a significant increase in mRNA levels of IL- $1 \beta$ and TNF- $\alpha$ in human skin ${ }^{19}$, but no changes in plasma level of these cytokines $24 \mathrm{~h}$ after the last exposure ${ }^{18}$. Three whole-body exposures of human subjects to UVA (340-400 nm) or UVB (311-313 nm) did not affect TNF- $\alpha$ and IL- $1 \beta$ serum level at several time points $(0-48 \mathrm{~h})\left(\right.$ ref. $\left.^{20}\right)$.

IL-6 acts in both pro-inflammatory and anti-inflammatory ways and is critical for healthy wound healing. Both foregoing cytokines, IL- 1 and TNF- $\alpha$ stimulate production of pleiotropic IL-6. Petit-Frère et al. also showed that release of IL-6 following UV radiation is wavelengthdependent and mediated by DNA damage, particularly by cyclobutane-pyrimidine dimmers ${ }^{21}$. Using a solar simulator, we found a different time-course of plasma IL-6 production after UVA and UVB treatment. While IL-6 levels were more pronounced after $4 \mathrm{~h}$ (16- and 68-fold) and also more normalized after $24 \mathrm{~h}$ (4- and 8-fold) in UVA treated groups (Table 2), in UVB exposed animals, enhanced IL-6 levels at $4 \mathrm{~h}$ (2- and 25-fold) were nearly unchanged at $24 \mathrm{~h}$ (5- and 25 - fold) following irradiation, see Table 1 . The IL- 6 profile that we found in mice skin following UVA and UVB irradiation (Table 3,4), contrasted with that in plasma as well as with results by Hiromi et al. Their immunohistochemical analysis of skin of the Hirosaki hairless rats exposed to UVB (275-305 nm; $200 \mathrm{~mJ} / \mathrm{cm}^{2}$ ) demonstrated that IL-6 increased after $6 \mathrm{~h}$, peaked at 12-24 h and gradually decreased at 48-96 h after the treatment ${ }^{15}$. In human subjects, Urbanski et al. found the peak IL- 6 concentration in plasma at $12 \mathrm{~h}$ after following the treatment with a UV source emitting light of 250-600 $\mathrm{nm}$ (emission peaks 300 and $360 \mathrm{~nm}$ ) $\left(\right.$ ref. $^{22}$ ). Narbutt et al. found no significant changes in IL-6 
level in plasma of human volunteers at $24 \mathrm{~h}$ following a single (3 MED) and repeated (10 x 0.7 MED) UVB (280-315 nm) exposure ${ }^{18}$. In contrast, massive increase in IL-6 mRNA level was found in human skin $24 \mathrm{~h}$ after a single exposure to 3 MED of UVB (280-315 nm) (ref. $\left.{ }^{17}\right)$. Similarly, repeated SSL (280-400 nm; 96\% UVA) exposures $\left(10 \times 120 \mathrm{~J} / \mathrm{m}^{2}\right)$ caused a significant increase in mRNA levels of IL-6 in human skin ${ }^{19}$. Similarly, irradiation of human volunteers with SSL caused a significant increase in IL-6 level in blister fluid $24 \mathrm{~h}$ after exposure to 1 MED (6-fold) and 2 MED (46-fold). But after repeated SSL treatment ( 4 x 0.3 MED), IL-6 secretion was normalized within $24 \mathrm{~h}$ after the last exposure ${ }^{16}$.

UVB-induced IL-6 generation as well as DNA damage has been reported to up-regulate IL-10 secretion ${ }^{23}$. IL-10 is produced by activated immune cells, in particular monocytes/macrophages and $\mathrm{T}$ cell subsets, infiltrating skin following UV irradiation ${ }^{24}$. Under our conditions, IL-10 plasma level following UVB exposure was reduced $4 \mathrm{~h}$ after the treatment and then normalized. In contrast, skin IL-10 level was minimally affected $4 \mathrm{~h}$ after UVB treatment but increased in the both groups after $24 \mathrm{~h}$. Shen et al. showed a significant up-regulation of IL-10 in UVB ( $3 \mathrm{MED}, 0.554 \mathrm{~mJ} / \mathrm{cm}^{2}$ ) treated hairless mice skin $24 \mathrm{~h}$ after irradiation that peaked at $72 \mathrm{~h}$ (12-fold increase) and decreased to control levels at $120 \mathrm{~h}$ (ref. ${ }^{25}$ ). A little different IL-10 profile was found in serum of Balb/c mice exposed to the dose of $15 \mathrm{~kJ} / \mathrm{m}^{2}$ of UV light (65\% UVB and 35\% UVA). IL-10 was increased $24 \mathrm{~h}$ after exposure, peaked at $36 \mathrm{~h}$ and was cleared at $72 \mathrm{~h}$ after irradiation $^{26}$. In human subjects exposed to $3 \mathrm{MED}$ of SSL (290-400 nm), IL-10 increase in skin was detected at 15 and $24 \mathrm{~h}$ after irradiation ${ }^{14}$. Local exposure of human volunteers to SSL ( 1 and 3 MED) induced a strong increase in IL-10 mRNA level $24 \mathrm{~h}$ after exposure ${ }^{13}$. Narbutt et al. found enhanced IL-10 mRNA level in skin ${ }^{17}$ but unchanged protein level in plasma ${ }^{18}$ at $24 \mathrm{~h}$ after a single exposure to 3 MED of UVB (280-315 nm) exposure. In UVA irradiated mice, we found a significant IL-10 increase in both plasma and skin samples after $24 \mathrm{~h}$. Shen et al. reported that UVA $\left(37.8 \mathrm{~J} / \mathrm{cm}^{2}\right)$ irradiation caused non-significant but detectable increase in IL-10 level in mice skin during 0-120 $\mathrm{h}$ after exposure ${ }^{25}$. On the other hand, repeated SSL (280-400 nm; 96\% UVA) exposures $\left(10 \times 120 \mathrm{~J} / \mathrm{m}^{2}\right)$ of human volunteers caused a significant increase in mRNA levels of IL-10 in $\operatorname{skin}^{19}$, but no changes in plasma protein level of the cytokine $24 \mathrm{~h}$ after the last exposure ${ }^{18}$. The results suggest that UVB-caused IL-10 increase is probably linked to enhanced leukocyte infiltration and DNA damage (thymine dimmer formation) (ref. ${ }^{27}$ ). In contrast, UVA-caused IL-10 accumulation is not linked to leukocyte infiltration (Fig. 3B) or DNA damage ${ }^{28}$, and may be connected to UVA-stimulated overproduction of reactive oxygen species and the following oxidant/antioxidant imbalance.

IL-12 is a pleiotropic cytokine that is a potent inducer of INF- $\gamma$ but it blocks IL-10 production and counteracts its activity $^{29}$. IL-12 is composed of two chains p40 and p35. Only the $70 \mathrm{kDa}$ dimmer is biologically active ${ }^{30}$. IL-12 is important in cutaneous allergies and inflammation and it has also been shown to block UV-induced immunosuppression. This effect includes stimulation of DNA repair but without increasing the level of the repair enzymes ${ }^{31}$. Using wild-type $(\mathrm{C} 3 \mathrm{H} / \mathrm{HeN})$ and IL-12-knockout mice Meeran et al. demonstrated that IL-12-deficiency significantly enhanced levels of pro-inflammatory cytokines (IL-1 $\beta$, TNF- $\alpha$ and IL-6) and COX-2 as well as leukocyte infiltration (MPO activity) following UV treatment ( $80 \%$ UVB; $180 \mathrm{~mJ} / \mathrm{cm}^{2}$ ) $\left(\right.$ ref. $\left.^{32}\right)$. As shown in Table 1 , under our conditions UVB treatment had no significant effect on IL-12(p40) plasma expression. However, a significantly increased IL-12(p40) level was detected in skin of mice treated with the higher UVB dose after $24 \mathrm{~h}$ (Fig. 1, Table 3). Following UVA exposure $\left(20 \mathrm{~J} / \mathrm{cm}^{2}\right)$, plasma amount of IL-12(p40) was significantly up-regulated after $24 \mathrm{~h}$. In skin, both UVA doses increased the protein level after $24 \mathrm{~h}$. Our results show that UVA is more potent in alteration of IL-12 production than UVB irradiation and modulates the UVB-induced immunosuppressive effect. In agreement with our results, Shen et al. described a significant IL-12 increase in the epidermis of UVA $\left(37.8 \mathrm{~J} / \mathrm{cm}^{2}\right)$ treated mice after $24 \mathrm{~h}$, which peaked at $72 \mathrm{~h}$ (6-fold increase) and then declined. In contrast, UVB irradiation $\left(0.554 \mathrm{~mJ} / \mathrm{cm}^{2}\right)$ resulted in a significant decrease in IL-12 levels $24 \mathrm{~h}$ after exposure and remained reduced for 4 days $^{25}$. In human subjects exposed to 3 MED of SSL (290-400 nm), no significant effect on IL-12 was found in skin tissue at 4-72 $\mathrm{h}$ after irradiation ${ }^{14}$. Although UV light has been reported to stimulate INF- $\gamma$ production ${ }^{25}$, under our condition we found no effect on the plasma cytokine in either UVB or UVA irradiated mice.

$\mathrm{UV}$-induced inflammation is also mediated by iNOS and COX-2 whose levels are normally low. We found upregulation of iNOS expression at $4 \mathrm{~h}$ following UVA and UVB treatment. This corresponds with the results by Chang et al. who found significantly increased iNOS level in mouse skin $6 \mathrm{~h}$ after UVB $\left(0.5 \mathrm{~J} / \mathrm{cm}^{2}\right)$ irradiation ${ }^{33}$. Repeated UVB exposure ( $80 \%$ of UVB, $7 \times 180 \mathrm{~mJ} / \mathrm{cm}^{2}$ ) of SKH-1 mice induced iNOS protein increase $24 \mathrm{~h}$ after the last treatment ${ }^{34}$. Unfortunately, we found no study on the effect of UVA radiation on iNOS expression skin in vivo. Concerning COX-2 protein expression, we found a moderate increase in mice exposed to the higher UVA dose at both time-points. No significant effect was detected following a single UVB exposure. It is not so surprising because COX-2 is understood to be mainly a marker of pro-inflammatory conditions and cancerogenesis that is linked to repeated UVB exposures ${ }^{35}$. Nevertheless in human keratinocytes, Buckman et al. found a moderate COX-2 protein increase at $6 \mathrm{~h}$ and strong one at $24 \mathrm{~h}$ after UVB (290-320 nm, $30 \mathrm{~mJ} / \mathrm{cm}^{2}$ ) exposure ${ }^{36}$. Narbutt et al. also found a massive increase of COX-2 expression in human skin $24 \mathrm{~h}$ after a single exposure to $3 \mathrm{MED}$ as well as repeated (10 x $0.7 \mathrm{MED})$ of UVB (280-315 nm) ( ref $^{17}$ ). Similarly, Rhodes et al. reported up-regulated COX-2 level in human skin $24 \mathrm{~h}$ after UV exposure (290-400 nm, peak $313 \mathrm{~nm}$ ) but not at 4 and $72 \mathrm{~h}$ (ref. $\left.{ }^{37}\right)$. Stimulation of COX-2 expression via UVA radiation of has been most probably described only in vitro ${ }^{38,39}$. A time-dependent study showed a rapid response with a peak of COX-2 
mRNA and protein expression at $1-2 \mathrm{~h}$ and $4 \mathrm{~h}$, respectively, following UVA exposure $\left(250 \mathrm{~kJ} / \mathrm{m}^{2}\right.$; the emission peak at $365 \mathrm{~nm}$ ) (ref. ${ }^{38}$ ). Mahns et al. further found that UVA-induced COX-2 up-regulation is wavelength-dependent. While 320-350 nm stimulated COX-2 expression, $350-400 \mathrm{~nm}$ was practically ineffective ${ }^{40}$.

MPO is commonly used as a marker of infiltrating leukocytes (macrophages and neutrophils) in the skin ${ }^{34}$. In agreement with the inflammatory character of the UVB irradiation, we found a dose-dependent increase in the MPO activity (2- and 6-fold) in skin $24 \mathrm{~h}$ after exposure (Fig. 3). These results correspond to a study by Casagrande et al. who found a dose-dependent increase in MPO activity in HRS/J hairless mice skin $6 \mathrm{~h}$ after single UV exposure (270-400 nm, 73\% UVB, 1.23-3.69 J/cm²) (ref. $\left.{ }^{41}\right)$. Similarly acute UVB treatment $\left(0.224 \mathrm{~J} / \mathrm{cm}^{2}\right)$ of female SKH-1 mice induced a significant increase in skin MPO activity $48 \mathrm{~h}$ after exposure. However, in male mice a minimal change in MPO activity was found ${ }^{42}$ and suggests that the effect is gender-dependent. On the other hand following UVA irradiation we found no significant effect on MPO activity. We also found no in vivo study that describes stimulation of MPO activity after UVA radiation to compare our results.

\section{CONCLUSION}

There are a number of reports on the effects of UVB radiation on inflammatory biomarkers in plasma and/ or skin. However, there is a lack of in vivo studies involving UVA light. Moreover, due to the use of different UV radiation sources, various experimental designs, animal models or human volunteers with differences in epidermal thickness and pigmentation, and different biological samples (skin, plasma, blister fluid) the results are often conflicting and thus it is difficult to generalise from, compare and/or relate to human beings. Here we have shown that a single exposure to solar simulated UVA and UVB light affected several cytokines at different time-courses in skin and plasma of mice. UVB- or UVA-induced changes in plasma parameters did not often correlate with those found in skin. This indicates that inflammatory marker analysis in plasma cannot substitute for analysis of skin tissue and vice versa. The variable quality, quantity and time-course of inflammatory response of the organism to UVA and UVB irradiation are connected to different mechanisms of action. Recent studies by Krutmann et al. indicate that the UV sources spectral output may be critical for the biological effects of UV light because there is some wavelength-dependent crosstalk at a molecular level that may significantly influence skin response ${ }^{1}$. For this reason, detailed in vivo and clinical trials arranged in dose- and time-dependent manner that will use the complete solar spectrum and isolated UVA and UVB wavebands together with exact characterization of UV sources are needed to understand and explain the molecular mechanisms of skin inflammation.

\section{ABBREVIATIONS}

COX-2, Cyclooxygenase 2; HRP, Horseradish peroxidase; iNOS, Inducible nitric oxide synthase; IL-1 $\alpha$, Interleukin-1 $\alpha$; IL-1 $\beta$, Interleukin-1 $\beta$; IL-6, Interleukin-6; IL-10, Interleukin-10; IL-12, Interleukin-12; IFN- $\gamma$, Interferon gamma; MED, Minimal erythema dose; MPO, Myeloperoxidase; TNF- $\alpha$, Tumor necrosis factor-alpha ; SSL, Solar simulated light; HTAB, hexadecyltrimethylammonium bromide.

\section{ACKNOWLEDGEMENTS}

We thank Dr. Sarka Ruzickova (Academy of Sciences) for help with plasma cytokine measurement and Nadezda Penakova (Department of Medical Chemistry and Biochemistry) for assistance during sample collection. This work was supported by the Institutional Support of Palacky University Olomouc.

\section{CONFLICT OF INTEREST STATEMENT}

Author's conflict of interest disclosure: The authors stated that there are no conflicts of interest regarding the publication of this article.

\section{REFERENCES}

1. Krutmann J. Ultraviolet A radiation-induced biological effects in human skin: relevance for photoaging and photodermatosis. J Dermatol Sci Suppl 2000;1:S22-6.

2. Svobodova A, Walterova D, Vostalova J. Ultraviolet light induced alteration to the skin. Biomed Pap Med Fac Univ Palacky Olomouc Czech Repub 2006;150:25-38.

3. Clydesdale GJ, Dandie GW, Muller HK. Ultraviolet light induced injury: immunological and inflammatory effects. Immunol Cell Biol 2001;79:547-68.

4. Casagrande R, Georgetti SR, Verri WA Jr, Dorta DJ, dos Santos AC, Fonseca MJ. Protective effect of topical formulations containing quercetin against UVB-induced oxidative stress in hairless mice. J Photochem Photobiol B 2006;84:21-7.

5. Soter NA. Acute effects of ultraviolet radiation on the skin. Semin Dermatol 1990;9:11-5.

6. Kondo S. The roles of keratinocyte-derived cytokines in the epidermis and their possible responses to UVA-irradiation. J Investig Dermatol Symp Proc 1999;4:177-83.

7. Takashima A, Bergstresser PR. Impact of UVB radiation on the epidermal cytokine network. Photochem Photobiol 1996;63:397-400.

8. Skiba B, Neill B, Piva TJ. Gene expression profiles of TNF-alpha, TACE, furin, IL-1 beta and matrilysin in UVA- and UVB-irradiated HaCat cells. Photodermatol Photoimmunol Photomed 2005;21:173-82.

9. Clingen $\mathrm{PH}$, Berneburg $\mathrm{M}$, Petit-Frère $\mathrm{C}$, Woollons $\mathrm{A}$, Lowe JE, Arlett $\mathrm{CF}$, Green $\mathrm{MH}$. Contrasting effects of an ultraviolet $\mathrm{B}$ and an ultraviolet A tanning lamp on interleukin-6, tumour necrosis factor-alpha and intercellular adhesion molecule-1 expression. Br J Dermatol 2001; 145:54-62.

10. Bradley PP, Priebat DA, Christensen RD, Rothstein G. Measurement of cutaneous inflammation: estimation of neutrophil content with an enzyme marker. J Invest Dermatol 1982;78:206-9.

11. Cruz PD Jr. Basic science answers to questions in clinical contact dermatitis. Am J Contact Dermat 1996;7:47-52.

12. Maverakis E, Miyamura Y, Bowen MP, Correa G, Ono Y, Goodarzi H. Light, including ultraviolet. J Autoimmun 2010;34:J247-57. 
13. Brink N, Szamel M, Young AR, Wittern KP, Bergemann J. Comparative quantification of IL-1 $\beta$, IL-10, IL-10r, TNF- $\alpha$ and IL-7 mRNA levels in UV-irradiated human skin in vivo. Inflamm Res 2000;49:290-6.

14. Hiromi N, Nakano H, Matsuzaki Y, Sawamura D, Hanada K. Immunohistochemical analysis of in vivo UVB-induced secretion of IL-1 $\alpha$ and IL-6 in keratinocytes. Mol Med Report 2011;4:611-4.

15. Barr RM, Walker SL, Tsang W, Harrison GI, Ettehadi P, Greaves MW, Young AR. Suppressed alloantigen presentation, increased TNFalpha, IL-1, IL-1Ra, IL-10, and modulation of TNF-R in UV-irradiated human skin. J Invest Dermatol 1999;112:692-8.

16. Kuhn M, Wolber R, Kolbe L, Schnorr O, Sies H. Solar-simulated radiation induces secretion of IL- 6 and production of isoprostanes in human skin in vivo. Arch Dermatol Res 2006;297:477-9.

17. Narbutt J, Lesiak A, Sysa-Jedrzejowska A, Wozniacka A, CierniewskaCieslak A, Boncela J, Jochymski C, Kozlowski W, Zalewska A, Skibinska M, Norval M. Repeated low-dose ultraviolet (UV) B exposures of humans induce limited photoprotection against the immune effects of erythemal UVB radiation. Br J Dermatol 2007;156:539-47.

18. Narbutt J, Lesiak A, Skibinska M, Wozniacka A, Sysa-Jedrzejowska A Lukamowicz J, van Loveren $\mathrm{H}$. Repeated doses of UVR cause minor alteration in cytokine serum levels in humans. Mediators Inflamm 2005;2005:298-303.

19. Narbutt J, Lesiak A, Sysa-Jedrzejowska A, Boncela J, Wozniacka A, Norval M. Repeated exposures of humans to low doses of solar simulated radiation lead to limited photoadaptation and photoprotection against UVB-induced erythema and cytokine mRNA upregulation.J Dermatol Sci 2007;45:210-2.

20. McLoone P, Man I, Yule S, Fluitman A, van Loveren H, Norval M, Gibbs NK. Whole-body UVB (TL-01) or UVA-1 irradiation does not alter the levels of immunomodulatory cytokines in the serum of human volunteers. Photodermatol Photoimmunol Photomed 2004;20:76-80.

21. Petit-Frère $C$, Clingen $P H$, Grewe $M$, Krutmann J, Roza L, Arlett $C F$, Green $\mathrm{MH}$. Induction of interleukin- 6 production by ultraviolet radiation in normal human epidermal keratinocytes and in a human keratinocyte cell line is mediated by DNA damage. J Invest Dermatol 1998;111:354-9.

22. Urbanski A, Schwarz T, Neuner P, Krutmann J, Kirnbauer R, Köck A Luger TA. Ultraviolet light induces increased circulating interleukin-6 in humans. J Invest Dermatol 1990;94:808-11.

23. Curiel-Lewandrowski C, Venna SS, Eller MS, CruikshankW, Dougherty I, Cruz PD Jr, Gilchrest BA. Inhibition of the elicitation phase of contact hypersensitivity by thymidine dinucleotides is in part mediated by increased expression of interleukin-10 in human keratinocytes. Exp Dermatol 2003;12:145-52.

24. Sabat R, Grütz G, Warszawska K, Kirsch S, Witte E, Wolk K, Geginat J. Biology of interleukin-10. Cytokine Growth Factor Rev 2010;21:33144

25. Shen J, Bao S, Reeve VE. Modulation of IL-10, IL-12 and INF- $\gamma$ in the epidermis of hairless mice by UVA (320-400 nm) and UVB (280-320 $\mathrm{nm}$ ) radiation. J Invest Dermatol 1999;113:1059-64.

26. Rivas JM, Ullrich SE. The role of IL-4, IL-10, and TNF-alpha in the immune suppression induced by ultraviolet radiation. J Leukoc Bio 1994;56:769-75.

27. Nishigori C, Yarosh DB, Ullrich SE, Vink AA, Bucana CD, Roza L, Kripke ML. Evidence that DNA damage triggers interleukin 10 cytokine production in UV-irradiated murine keratinocytes. Proc Natl Acad Sci U S A 1996;93:10354-9.

28. Svobodová AR, Galandáková A, Šianská J, Doležal D, Lichnovská R, Ulrichová J, Vostálová J. DNA damage after acute exposure of mice skin to physiological doses of UVB and UVA light. Arch Dermatol Res 2012;304:407-12

29. Tripp CS, Wolf SF, Unanue ER. Interleukin 12 and tumor necrosis factor alpha are costimulators of interferon gamma production by natural killer cells in severe combined immunodeficiency mice with listeriosis, and interleukin 10 is a physiologic antagonist. Proc Natl Acad Sci USA 1993;90:3725-9.

30. Mattner F, Fischer S, Guckes S, Jin S, Kaulen H, Schmitt E, Rude E, Hermann T. The interleukin-12 subunit p40 specifically inhibit effects of interleukin-12 heterodimer. Eur J Immunol 1993;23:2202-8.

31. Molenda M, Mukkamala L, Blumenberg M. Interleukin IL-12 blocks a specific subret of transcriptional profile responsive to UVB in epidermal keartinocytes. Mol Immunol 2006;43:1933-40.

32. Meeran SM, Punathil T, Katiyar SK. IL-12 deficiency exacerbates inflammatory responses in UV-irradiated skin and skin tumors. J Invest Dermatol 2008;128:2716-27.

33. Chang EJ, Kundu JK, Liu L, Shin JW, Surh YJ. Ultraviolet B radiation activates NF-KB and induces iNOS expression in HR-1 hairless mouse skin: role of IKB kinase- $\beta$. Mol Carcinog 2011;50:310-7.

34. Khan N, Syed DN, Pal HC, Mukhtar H, Afaq F. Pomegranate fruit extract inhibits UVB-induced inflammation and proliferation by modulating NF-KB and MAPK signaling pathways in mouse skin. Photochem Photobiol 2012;88:1126-34.

35. Müller-Decker K. Cyclooxygenase-dependent signaling is causally linked to non-melanoma skin carcinogenesis: pharmacological, genetic, and clinical evidence. Cancer Metastasis Rev 2011;30:343-61.

36. Buckman SY, Gresham A, Hale P, Hruza G, Anast J, Masferrer J, Pentland AP. COX-2 expression is induced by UVB exposure in human skin: implications for the development of skin cancer. Carcinogenesis 1998;19:723-9.

37. Rhodes LE, Gledhill K, Masoodi M, Haylett AK, Brownrigg M, Thody AJ, Tobin DJ, Nicolaou A. The sunburn response in human skin is characterized by sequential eicosanoid profiles that may mediate its early and late phases. FASEB J 2009;23:3947-56.

38. Bachelor MA, Silvers AL, Bowden GT. The role of p38 in UVA-induced cyclooxygenase-2 expression in the human keratinocyte cell line, HaCaT. Oncogene 2002;21:7092-9.

39. Kostyuk V, Potapovich A, Stancato A, De Luca C, Lulli D, Pastore S, Korkina L. Photo-oxidation products of skin surface squalene mediate metabolic and inflammatory responses to solar UV in human keratinocytes. PLoS One 2012;7:e44472.

40. Mahns A, Wolber R, Stäb F, Klotz LO, Sies H. Contribution of UVB and UVA to UV-dependent stimulation of cyclooxygenase-2 expression in artificial epidermis. Photochem Photobiol Sci 2004;3:257-62.

41. Casagrande R, Georgetti SR, Verri WA Jr, Dorta DJ, dos Santos AC, Fonseca MJ. Protective effect of topical formulations containing quercetin against UVB-induced oxidative stress in hairless mice. J Photochem Photobiol B 2006;84:21-7.

42. Thomas-Ahner JM, Wulff BC, Tober KL, Kusewitt DF, Riggenbach JA, Oberyszyn TM. Gender differences in UVB-induced skin carcinogenesis, inflammation, and DNA damage. Cancer Res 2007;67:3468-74. 